\title{
Insights into purification of contaminated water with activated charcoal derived from hamburger seed coat
}

\author{
L. O. Ajala ${ }^{1}$ (1) E. E. Ali ${ }^{1}$ N. A. Obasi ${ }^{2}$ (D) T. O. Fasuan ${ }^{3} \cdot$ I. O. Odewale ${ }^{4} \cdot$ J. O. Igidi ${ }^{5} \cdot$ J. Singh $^{6}$
}

Received: 27 March 2021 / Revised: 15 July 2021 / Accepted: 22 July 2021 / Published online: 30 July 2021

(c) Islamic Azad University (IAU) 2021

\begin{abstract}
Hamburger seed coat is a readily available agricultural waste product generated in large quantities annually. In this study, activated charcoal was produced using hamburger seed coat activated with zinc chloride and its physicochemical properties such as fixed carbon, specific surface area, volatile matter, ash and moisture content were investigated. Scanning electron microscopy and Fourier transform infrared spectrometry techniques were used to study the surface morphology and variations in the absorption bands of functional groups, respectively. The adsorbent biosorption of pollutants abilities from contaminated water was investigated using standard methods with a view to ascertaining the adsorbent purification potential. The results showed that the adsorbent was of high porous structure with adsorption capacity significantly correlated with iodine value. The physicochemical properties of the contaminated water treated with the adsorbent were comparable with commercial activated charcoal (control)-treated water but indicated a significant decrease $(p<0.05)$ in the $\mathrm{pH}$, temperature, total dissolved solids, total suspended solids, conductivity, turbidity, alkalinity, hardness, biochemical oxygen demand, chemical oxygen demand, anions and heavy metal ions when compared to the untreated water. With the exception of alkalinity, other parameters investigated in the water treated with the test adsorbent fell within the standards set for potable water. Results of this study therefore revealed possibility of converting large quantities of hamburger seed coat wastes that could constitute environmental pollution to a profitable product that could be employed for treatment of wastewater.
\end{abstract}

Keywords Adsorbent $\cdot$ Agricultural waste $\cdot$ Physicochemical properties $\cdot$ Pollutants $\cdot$ Water treatment

\section{Introduction}

Editorial responsibility: J. Chen.

L. O. Ajala

loajala@akanuibiampoly.edu.ng

1 Department of Science Laboratory Technology, Akanu Ibiam Federal Polytechnic, Unwana, Nigeria

2 Department of Medical Biochemistry, Alex Ekwueme Federal University, Ndufu-Alike, Nigeria

3 Department of Food Technology, Akanu Ibiam Federal Polytechnic, Unwana, Nigeria

4 Department of Ceramic and Glass Technology, Akanu Ibiam Federal Polytechnic, Unwana, Nigeria

5 Department of Chemistry, Ebonyi State University, Abakaliki, Nigeria

6 School of Biochemical Engineering, IIT (BHU), Varanasi, India
The majority of public or municipal water is from untreated sources, whether from a well, reservoir or natural body. These waters may contain living organisms, organic and inorganic substances that render them unfit for uses (Zhou et al. 2014; Singh et al. 2020). The search for solutions to clean contaminated water to be used in the laboratories is becoming urgent to guarantee the reliability of the results being reported.

Physical and chemical methods of water purifications such as distillation, filtration, deionization and flocculation had been applied in the past but are faced with one or other limitations (Kurniawan et al. 2006; Wang et al. 2010). Recently, adsorption of pollutants in water over activated carbons has been found to be a better option in terms of its efficiency in adsorbing a broad range of pollutants, fast adsorption kinetics, simplicity of design and relative abundance and low cost of starting materials (Ademiluyi et al. 2009; Reza et al. 2020). 
Activated charcoal (AC) also known as activated carbon is produced by the controlled thermalization of carbonaceous material (Rahman et al. 2006). This activation produces a porous material with a large surface area ranging from 500 to $1500 \mathrm{~m}^{2} \mathrm{~g}^{-1}$ and a high affinity for pollutants from gas or liquid streams (Rahman et al. 2006). It is now applicable in many fields of operation, particularly on a commercial scale for a number of purposes such as effluent treatment (Yusufu et al. 2012; Marichelvan and Azhagurajan 2018), water purification (Ademiluyi et al. 2009; Sivakumar et al. 2012; Hegazi 2013; Ijaola et al. 2013; Ukpaka and Edwin 2013; Abraham et al. 2018), pesticide adsorbent (Gokhale et al. 2020), and heavy metal sorption (Ijaola et al. 2013; Mopoung et al. 2015; Elelu et al. 2019; Özsin et al. 2019). It is also applicable in medicine for removal of poisons (Wang et al. 2010) and recently, as filter in nose masks for the prevention against novel Coronavirus SARS-CoV-2 (Reza et al. 2020).

$\mathrm{AC}$ is principally used for purification of contaminated water due to its high capacity for adsorption of compounds that produce bad taste, colour and odour. It can remove total suspended solids (TSS) and biochemical oxygen demand (BOD) effectively (Siong et al., 2013). Also, it has been used for reduction of chemical oxygen demand (COD), turbidity, total dissolved solids (TDS) and normalization of $\mathrm{pH}$ of contaminated water (Ademiluyi et al. 2009; Ijaola et al. 2013; Mopoung et al. 2015). In addition, adsorption of heavy metals in wastewater on $\mathrm{AC}$ has been reported (Mopoung et al. 2015).

Commercially, ACs are still expensive due to the use of nonrenewable and relatively high-cost starting materials (Martin et al. 2003; Chakraborty et al. 2005; Singh and Mishra 2021). In developing countries such as Nigeria, where the economic power plays a very big role, it is better to find relatively low-cost adsorbents for purification and decontamination of water since potable water is most desirable for domestic and industrial uses. Recently, researchers have tried to produce ACs using renewable, readily available and cheaper precursors which are mainly industrial and agricultural waste products such as bagasse (Boonpoke et al. 2011), activated sludge (Al-Qodah and Shawabkah 2009), rice husk (Boonpoke et al. 2011; Hegazi 2013; Subramani and Revathi 2015; Ajala et al. 2020), coconut shell (Rahman et al. 2006; Gawande and Kaware 2017), sawdust (Ukpaka and Edwin 2013; Alzaydien 2016), empty palm fruit bunch (Abdul-Khalil et al. 2013; Hidayat and Sutrisno 2017), physic nut waste (Pechyen et al. 2007; Sricharoenchaikul et al. 2008; Elelu et al. 2019), pruning mulberry shoot (Wang et al. 2010), bamboo (Ademiluyi et al. 2009; Ijaola et al. 2013), chickpea (Özsin et al. 2019), acorn shell (Saka 2012) and some plant seeds (Sivakumar et al. 2012; Mopoung et al. 2015). In the same line of action, this research focuses on the utilization of hamburger seed (Mucuna sloanei) coat, a non-edible part of the plant as a raw material for the production of $\mathrm{AC}$ for purification of contaminated water. The use of this agricultural waste has not been reported anywhere in the literature for the production of AC.

Hamburger seed is among the most commonly used soup condiments in South-East Nigeria. As a result of this, an enormous load of non-commercial hamburger seed coat is generated each year as agricultural and industrial wastes which constitute environmental soil pollution. Currently, extensive efforts are being made to advance the reduction of the large quantities of hamburger seed coat waste through burning in an open air. This practice also causes environmental air pollution. Thus, converting hamburger seed coat waste into a valuable and profitable asset will be most lucrative to humans and attractive to the environment. This research is therefore aimed at proffering a novel solution for hamburger seed waste management, with the goal of harnessing economic profits as well as preserving the environment. Relative availability and abundance make hamburger seed coat an ideal candidate for AC production. Conversion of this cheap and abundant agricultural waste into an AC will serve many purposes: firstly, unwanted agricultural waste is converted to a useful and value-added product; contribute to solving contaminated water treatment problems; and helps in the management of solid waste which will eventually enhance the aesthetic conditions of the environment.

In the present study, hamburger seed coat was collected from Abakaliki, Nigeria (Fig. 1) (co-ordinate $6^{\circ} 19.491^{\prime} \mathrm{N}$ $8^{\circ} 6.821^{\prime}$ E) in August 2019 for the preparation of AC. It was carbonized, activated and then optimized using iodine adsorption with regard to activation concentration, impregnation ratio, impregnation time, impregnation temperature, pyrolysis temperature and pyrolysis time. Physicochemical characterization of the prepared AC was also carried out. The physicochemical assay of the filtrate obtained after a fixed bed adsorption study was analysed for both commercial (CAC) and hamburger seed coat AC (HAC). Appropriate quality control and quality assurance measures have then been implemented. Finally, both treated water and untreated water were statistically and chemometrically studied.

\section{Materials and methods}

\section{Sample collection and treatment}

The seed coat of hamburger (M. sloanei) was collected from the processing plant at Abakaliki, Nigeria (Fig. 1). The waste was transported to the Chemistry Research Unit of the Department of Science Laboratory Technology, Akanu Ibiam Federal Polytechnic Unwana, Nigeria. Extraneous materials were removed, and the waste was repeatedly washed with deionised water to remove other contaminants and thereafter sun-dried for 3 days. The pre-treated raw material was pulverized and sieved, and particle sizes of 500 


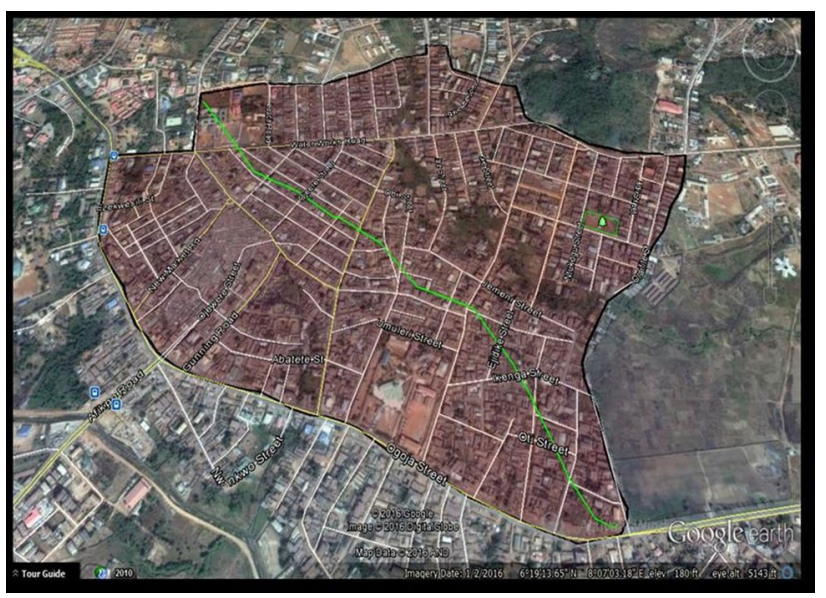

Fig. 1 Map of Abakaliki, Ebonyi State, Nigeria, where the hamburger seed coat was collected. ( Source: Google Digital Globe 2016)

to $600 \mu \mathrm{m}$ were collected and stored in an air-tight container for further study. The surface water used for adsorption studies was collected from a surface flowing stream within the water reservoir area of the Akanu Ibiam Federal Polytechnic Unwana, intended to be dammed and supplied for laboratory uses. Temperature and $\mathrm{pH}$ were measured in situ. CAC (Calgon carbon, F-300) was used as control, and other chemicals were of analytical grades and were sourced from $\mathrm{BDH}$ Chemicals Limited, UK.

\section{Carbonization, activation and optimization}

Carbonization and activation were performed according to standard methods (Wang et al. 2010; Olagunju et al. 2015) with slight modifications. Briefly, the raw material was fed into the reactor (fluidized bed) of a locally fabricated pyrolysis plant and carbonized at $400{ }^{\circ} \mathrm{C}$ for $1 \mathrm{~h}$. After carbonization, char produced, hamburger seed coat charcoal (HSC) was allowed to cool and pulverized. A part of the HSC was impregnated with zinc chloride at varying concentrations $(0.5,1.0,1.5,2.0,2.5) \mathrm{mol} \mathrm{dm}^{-3}$ at $1: 1,1: 2,1: 3,2: 1,3: 1$ w/v (precursor: $\mathrm{ZnCl}_{2}$ ) ratios for $5,10,15,20$, and $25 \mathrm{~h}$ at impregnation temperatures of $20,40,60,80,100{ }^{\circ} \mathrm{C}$. The slurries formed were carbonized in a muffle furnace (FisherThermo Scientific, USA) at varying temperatures (250, 350, $450,550,650)^{\circ} \mathrm{C}$ for $1.0,1.5,2.0,2.5,3.0 \mathrm{~h}$ after which they were removed and cooled in an ice-water bath. Excess water was drained out and allowed to stand at room temperature. The residual activating reagent $\left(\mathrm{ZnCl}_{2}\right)$ and surface ash were removed from the carbonized products with $0.10 \mathrm{~mol} \mathrm{dm}^{-3}$ hydrochloric acid. They were furthered washed and rinsed with double-distilled deionised water to remove residual acid until a neutral $\mathrm{pH}$ ( of 7) was achieved. They were ovendried (Gallenkamp, US) at $110^{\circ} \mathrm{C}$ until constant weights were attained. The individual weight of the HAC was taken and the yield calculated. Adsorption on iodine of the various ACs with respect to activation concentration, impregnation ratio, impregnation temperature, pyrolysis temperature and pyrolysis time were investigated to determine the optimum conditions for the preparation.

\section{Physical and chemical characterization}

The pyrolyzed HSC and HAC were subjected to several batteries of analyses to establish the superiority of HAC as an adsorbent over HSC. Carbon yield was calculated from the sample weights after pyrolysis and activation, respectively, to their initial weights. Bulk density, fixed carbon, volatile matter, ash and moisture contents were determined according to established methods (AOAC 2000). Iodine value was determined according to the methods outlined by ASTM (2006). Porous properties were estimated using micrometric surface area and porosimetry system (ASAP 2010, Micrometric Inc., USA). The surface area was calculated from $\mathrm{N}_{2}$ adsorption isotherms using Brunauer-Emmett-Teller (BET) equation. Scanning electron microscope (Phenom ProX, Thermo Scientific, Netherland) was used to distinguish between the surface morphologies, and elemental compositions of the surface were determined with energy dispersive X-ray spectrometer (ED-XRS) coupled to the SEM. Fourier transform infrared spectrometer (Carg 630, Agilent, UK) was used to study the variations in the absorption bands of functional groups in the HSC and HAC in the range of $4000-400 \mathrm{~cm}^{-1}$.

\section{Fixed bed adsorption studies}

The HAC and CAC were packed separately into different columns with two open ends. One end of the columns was closed with glass wool to prevent the adsorbents from flowing out. The columns were mounted vertically with the open ends upward. Through the open ends of the columns, contaminated water collected was poured through the columns already packed with the adsorbents. The filtrates were collected separately and ready for physicochemical assay.

\section{Physicochemical properties of adsorbates}

Physicochemical properties that are essential to determine the quality of water in the untreated water, filtrate from CAC (FCAC) and the filtrate from HAC (FHAC) were analysed separately using standard methods (APHA 2005). pH was determined with $\mathrm{pH}$ meter (PHS-3C, Germany), temperature measurement was carried out with the aid of mercury in glass thermometer, the colour measurement was taken using a colorimeter (CR-400, Minolta Chroma Meter, Japan), and the odour was determined with sensory organ. Total suspended solids and total dissolved solids were, respectively, determined 
gravimetrically by filtration and after the samples were ovendried to constant weight at $105^{\circ} \mathrm{C}$. Alkalinity was determined by titrating $0.02 \mathrm{~N}\left(\mathrm{H}_{2} \mathrm{SO}_{4}\right)$ solution with the water samples. Chloride was estimated by titration method using silver nitrate $(0.043 \mathrm{~N})$ as standard solution and potassium chromate as indicator. Total hardness was estimated by EDTA complexometric titration method. Chemical oxygen demand was determined by boiling the water sample under reflux with potassium dichromate and silver sulphate catalyst in strong sulphuric acid and titrated with ferrous ammonium sulphate using ferroin as indicator. Biological oxygen demand was determined using the Winkler titration method. Turbidity was measured with Nephelo-turbidity meter (Systronics type No 131), while electrical conductivity was measured with a conductivity meter at $25^{\circ} \mathrm{C}$. Nitrate, phosphate and sulphate were measured spectrometrically with UV-visible spectrophotometer (390, Buck Scientific, USA), while the metallic ions were determined with the aid of atomic absorption spectrometer (Unicam 900, USA).

\section{Analytical method control}

Appropriate parallel quality control and quality assurance measures were carried out. All chemicals used were checked for possible trace metal contamination. Double-distilled deionized water was employed for the preparation of all requisite solutions. Samples were carefully handled to avoid cross-contamination. All glassware used for analyses were previously soaked in $10 \%$ nitric acid (v/v) for $24 \mathrm{~h}$, washed with detergent, rinsed with double-distilled deionised water and dried in a clean laboratory oven. Standard solutions of all the heavy metals in the filtrates were prepared in five different concentrations to obtain respective calibration curves. Blanks were prepared and similarly treated as samples to give room for blank correction. Blanks and standard solutions were co-analysed with the analytical samples. Linear ranges were obtained for the target ions with good correlation coefficients $\left(\mathrm{R}^{2} \geq 0.9993\right)$. The limits of detection of the elements analysed were determined and were found to be $0.003,0.008,0.005,0.020,0.015,0.025,0.010,0.030$ and $0.001 \mathrm{mg} \mathrm{dm}^{-3}$ for $\mathrm{Cd}^{2+}, \mathrm{Ni}^{2+}, \mathrm{Pb}^{2+}, \mathrm{Mn}^{2+}, \mathrm{Fe}^{2+}, \mathrm{Zn}^{2+}$ $\mathrm{Cu}^{2+}, \mathrm{Cr}^{3+}$ and $\mathrm{As}^{3+}$, respectively. Recovery tests were also performed by spiking a known concentration of the analyte to the samples and results were in the range of $93-102 \%$. The precision (relative standard deviation) of 10 replicate determinations of the target ions was calculated; this ranged from 0.08 to $3.8 \%$. Details of method validation are stated in the supplementary material (Table S1).

\section{Statistical and chemometric analyses}

Three independent determinations were performed on each untreated, FHAC and FCAC. Data were recorded as mean \pm standard deviation of the replicate values. A one-way analysis of variance (ANOVA) was used to analyse the difference between experimental groups. Means were compared by the Duncan' multiple range test, and significance was established at 5\% level using SPSS for Windows 2008 (version 15.0). Principal component analysis (PCA) was employed to express an overview and differences among the treated and untreated water samples. Inter-correlation of the physicochemical properties of the water samples was studied with the Person correlation coefficient and agglomerative hierarchical clustering (AHC) tools. Detailed chemometric analysis results can be found in the supplementary material (Table S2).

\section{Results and discussion}

\section{Optimization conditions}

\section{Effect of concentration of activating agent}

The result of the effect of different concentrations of the activating agent $\left(\mathrm{ZnCl}_{2}\right)$ on the iodine adsorption capacity of the HAC is shown in Fig. 2a. The optimum value (1053 $\mathrm{mg} \mathrm{gm}^{-1}$ ) of iodine adsorption on the surface of the test adsorbent was reached at a corresponding concentration of $1.0 \mathrm{~mol} \mathrm{dm}^{-3}$, while impregnation ratio, temperature and time were held constant at 1:2 (precursor: activating agent), $60{ }^{\circ} \mathrm{C}$ and $20 \mathrm{~h}$, respectively. Below this concentration, the iodine number was significantly lowered. This could probably be due to insufficient activator to react with the precursor and create more internal pore structures. At the optimum value of iodine adsorption, a higher reaction rate could have occurred between the activating agent and the precursor leading to the release of more volatile components with the corresponding improvement in porous characteristics (Saka 2012; Mopoung et al. 2015). As the concentration increased beyond this value, adsorption capacity decreased progressively. This could be attributed to the fact that the micropore structures of the precursor deteriorated as a result of excessive activation (Mopoung et al. 2015). The change in the adsorption capacities is an evidence that the activating agent had caused chemical changes in the precursor.

\section{Effect of impregnation ratio}

The variations in the iodine value of the activated charcoal under test versus the impregnation ratio are shown in Fig. 2b. At the constant volume of the activator, there was a gradual increase in the iodine values with a concomitant decrease in adsorbent quantity. This could be linked to the reason stated earlier. The iodine value was at an optimum level at the ratio of 1:2 of the precursor to the activating agent, while impregnation concentration, temperature and 
(a)

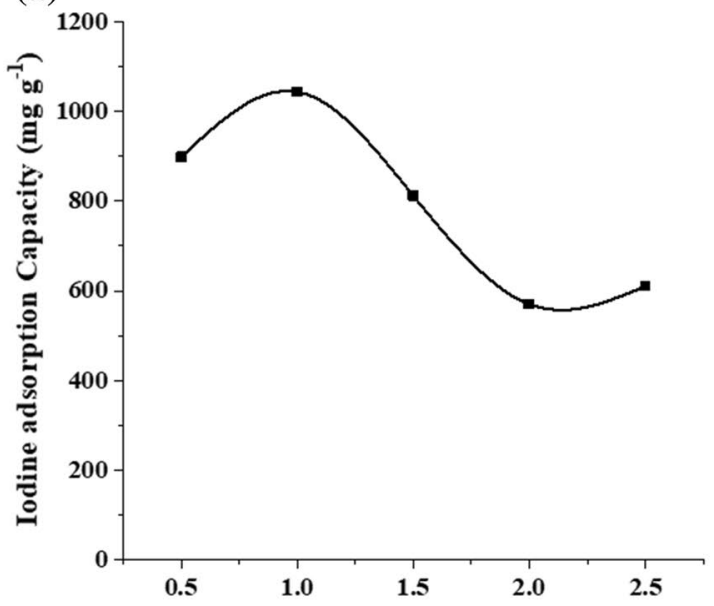

(c) Impregnation concentration $\left(\mathrm{mol} \mathrm{dm}^{-3}\right)$

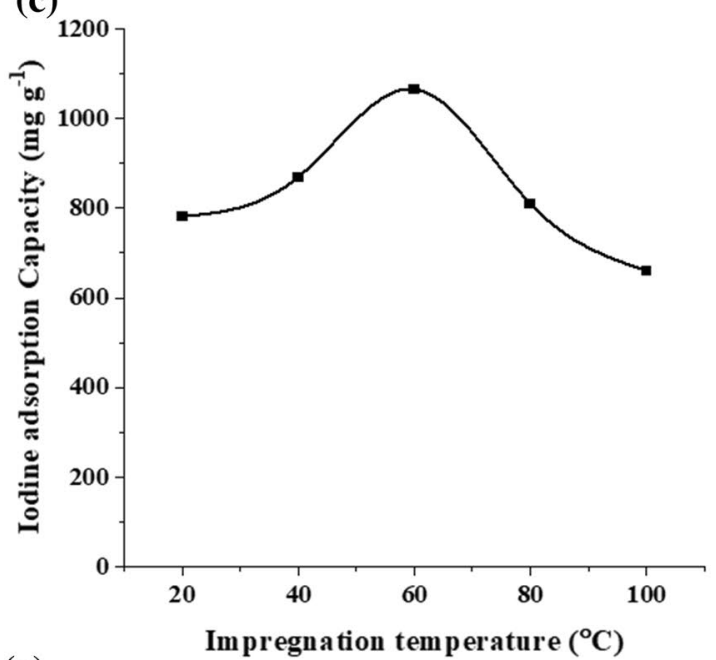

(e)

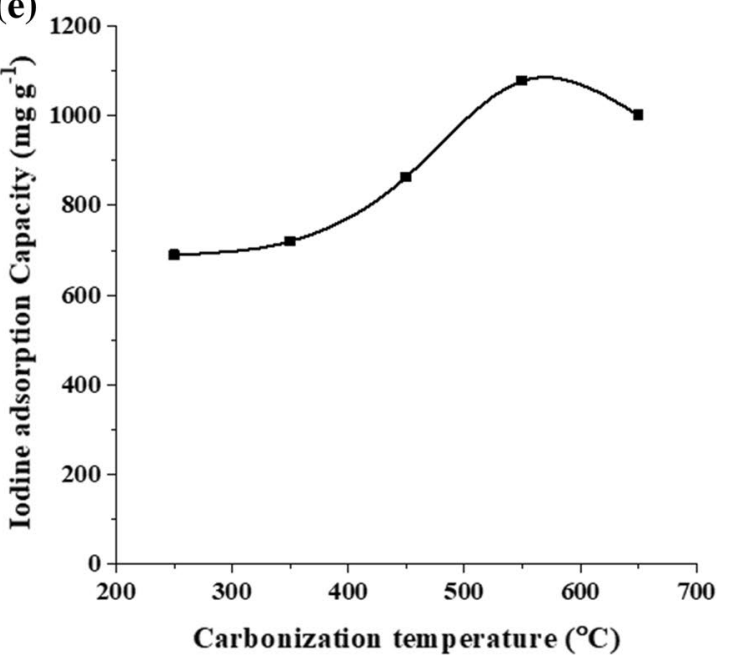

(b)

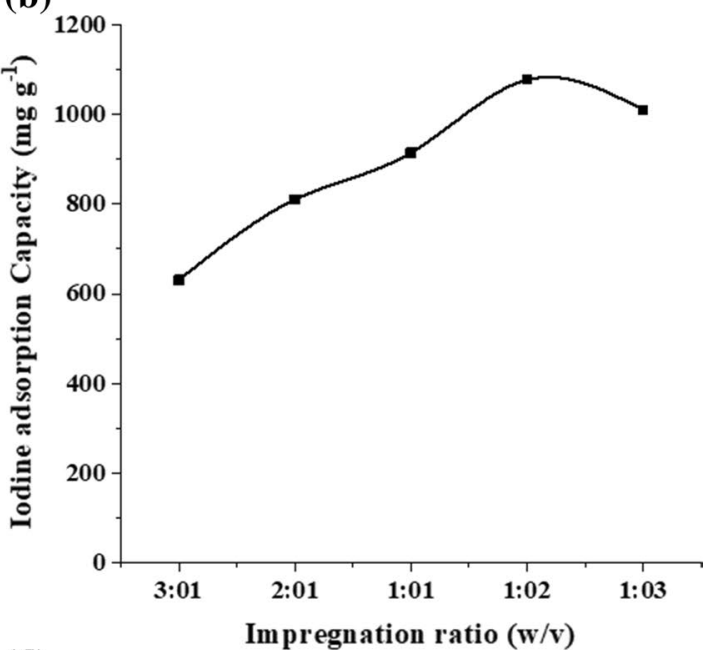

(d)
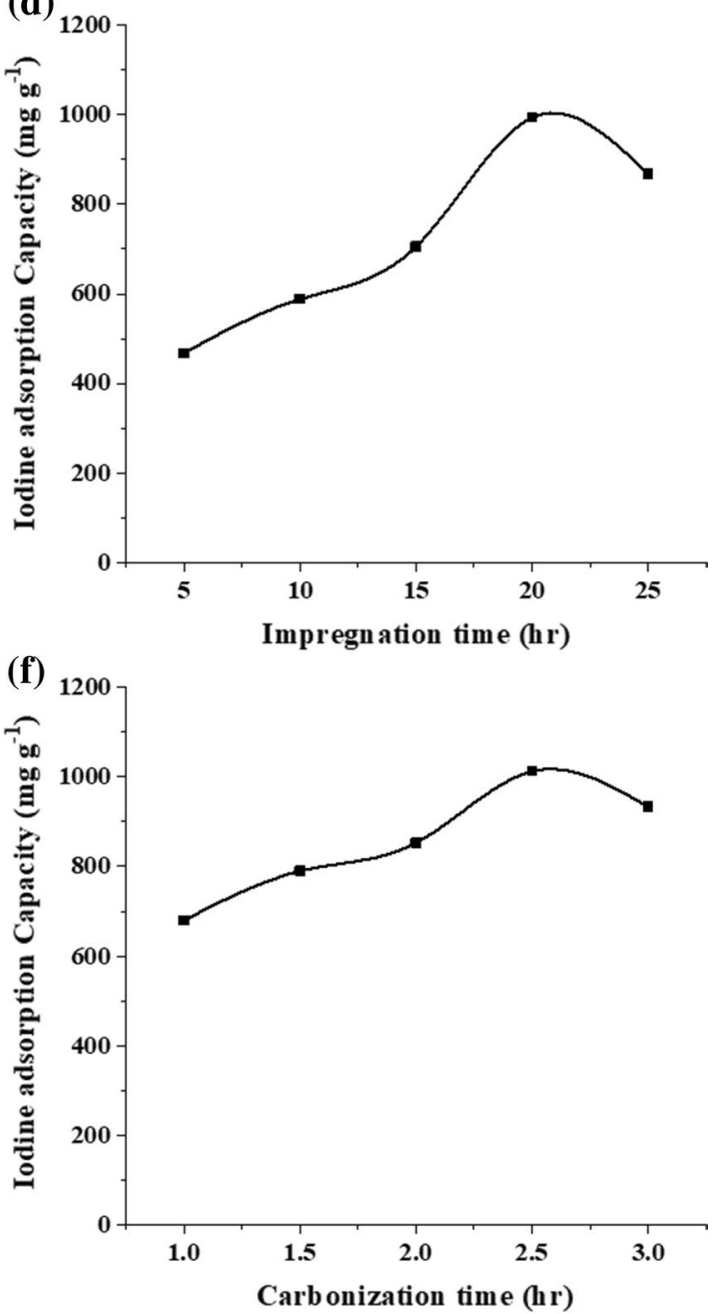

Fig. 2 Effects of a different concentrations of activating agent, $\mathbf{b}$ impregnation ratio, $\mathbf{c}$ impregnation temperature, $\mathbf{d}$ impregnation time $\mathbf{e}$ carbonization temperature, $\mathbf{f}$ carbonization time on the iodine adsorption capacity of HAC 
time were kept constant at $1.0 \mathrm{~mol} \mathrm{dm}{ }^{-3}, 60{ }^{\circ} \mathrm{C}$ and $20 \mathrm{~h}$, respectively. Thereafter, the iodine value gradually dropped as the impregnation ratio increased. This could be credited to a more extensive reaction as stated earlier. The implication of these observations in this study is that for optimum adsorption to take place in HAC, the weight of the precursor to that of the activating solution should be maintained at ratio 1:2.

\section{Effect of impregnation temperature}

The effects of differences in impregnation temperature on the iodine adsorption capacity of HAC are shown in Fig. 2c. The impregnation temperature is known to influence the pore structure of activated charcoal with respect to adsorption capacity (Wang et al. 2010). The iodine values increased gradually with the temperature of impregnation, while impregnation concentration, ratio and time were kept constant at $1: 2,60^{\circ} \mathrm{C}$ and $20 \mathrm{~h}$, respectively. When the temperature was extended to $60^{\circ} \mathrm{C}$, iodine adsorption was at its optimal. At temperature beyond this value, it was noticeable that iodine adsorption capacity decreased. The reason for this has been adduced earlier. Overall, the change in the adsorption capacity of iodine progressively is an indication that chemical changes might have occurred in the precursor.

\section{Effect of impregnation time}

Iodine adsorption efficiency of MAC increased with a corresponding increase in the impregnation time until maximum adsorption was achieved at $20 \mathrm{~h}$ (Fig. 2d), while impregnation concentration, ratio and temperature were kept constant at $1.0 \mathrm{~mol} \mathrm{dm}{ }^{-3}, 1: 2$ and $60^{\circ} \mathrm{C}$, respectively. At this time, the porous pores might have been saturated with the activating (Subramani and Revathi, 2015). When the impregnation time was extended beyond the critical time, there was no significant change in the iodine adsorption capacity of the test adsorbent, indicating that there were no more porous networks for diffusion of the activating agent to occupy.

\section{Effect of carbonization temperature}

The pyrolysis temperature is an influential factor that determines the adsorption capacity of activated charcoal (Wang et al. 2010). The variation in iodine values of the adsorbent was investigated as a function of pyrolysis temperature (Fig. 2e), while carbonization time was kept constant at $2.5 \mathrm{~h}$. As shown, the iodine value increased progressively with an increase in activation temperature and then decreased when the temperature exceeded $550^{\circ} \mathrm{C}$. As the temperature increased, chemical changes might have occurred in the precursor, facilitating the formation of more pores ready for adsorption at a lower temperature. Lower iodine adsorption was recorded as the temperature was increased beyond the critical value. The reason for this has been explained above.

\section{Effect of carbonization time}

The effect of pyrolysis time as shown in Fig. $2 \mathrm{f}$ indicates that adsorption efficiency increased with a corresponding increase in pyrolysis time before optimum time of $2.5 \mathrm{~h}$ was attained while carbonization temperature was kept at $550{ }^{\circ} \mathrm{C}$. Beyond this time, there was a noticeable decrease in the iodine adsorption capacity as a result of the reason adduced above. This signifies that pyrolysis time has a significant influence on the adsorption capacity of the HAC.

\section{Characterization of adsorbents}

\section{Physical and chemical properties}

The results of physical and chemical properties of the HSC and HAC are presented in Table 1. Also, Table 2 compares the properties of the HAC with similar ACs in the literature. The yield of the HSC was higher than that of the HAC (Table 1). This is expected because HSC was produced at a relatively low temperature, while HAC was prepared at a higher temperature. Charcoal with high bulk density is suitable for water treatment, while low-density charcoal suspends on water and therefore lowers the efficiency (Sivakumar et al. 2012). Charcoal with acceptable density helps to improve the filtration rate by forming an even cake on the filter surface (Elelu et al. 2019). The study revealed that the bulk density for HAC $\left(0.52 \mathrm{~g} \mathrm{~cm}^{-3}\right)$ was lower than $0.74 \mathrm{~g} \mathrm{~cm}^{-3}$ reported for the HSC but was in close agreement with $0.59 \mathrm{~g} \mathrm{~cm}^{-3}$ determined in coconut shell AC (Gawande and Kaware 2017).

Researches had reported that the rate of adsorption of contaminants in wastewater increases with respect to low moisture content in the adsorbent (Rangaraj et al. 2002; Elelu et al. 2019). There was a reduction in the moisture content after the char was activated, suggesting that porosity has been introduced extensively into the carbon network (Pechyen et al. 2007). Also, low ash content signifies a larger proportion of carbon content and the high proportion of ash in AC lowers the adsorption of pollutants; hence, high ash content is not desirable (Pechyen et al. 2007; Jacob et al. 2017). Since ash is an indicative of inorganic constituent, charcoals with low ash content had been used effectively to remove inorganic contaminants in wastewater (Sivakumar et al. 2012). Ash content of the HAC in this study was higher than 1.9\% found in bagasse AC (Boonpoke et al. 2011), indicating lower activity. The ash (2.74\%) and moisture (2.66\%) contents were better than $4.01 \%$ and $8.96 \%$, respectively, 
Table 1 Result of characterization of hamburger seed coat charcoal (HSC) and hamburger seed coat-based activated charcoal (HAC)

\begin{tabular}{|c|c|c|}
\hline Property & $\mathrm{HSC}$ & HAC \\
\hline Yield $(\%)$ & $85.62 \pm 2.94$ & $73.30 \pm 3.68$ \\
\hline Volatile matter (\%) & $12.86 \pm 0.76$ & $15.70 \pm 1.21$ \\
\hline Fixed carbon (\%) & $74.20 \pm 4.08$ & $64.56 \pm 2.11$ \\
\hline Ash content $(\%)$ & $9.06 \pm 0.63$ & $2.74 \pm 0.22$ \\
\hline Moisture content (\%) & $6.40 \pm 0.38$ & $2.66 \pm 0.11$ \\
\hline Bulk density $\left(\mathrm{g} \mathrm{cm}^{-3}\right)$ & $0.74 \pm 0.02$ & $0.52 \pm 0.04$ \\
\hline Iodine number $\left(\mathrm{mg} \mathrm{g}^{-1}\right)$ & $514 \pm 5.02$ & $1083 \pm 7.02$ \\
\hline Surface area $\left(\mathrm{m}^{2} \mathrm{~g}^{-1}\right)$ & $440 \pm 5.46$ & $1029 \pm 9.75$ \\
\hline Pore volume $\left(\mathrm{cm}^{3} \mathrm{~g}^{-1}\right)$ & $0.32 \pm 0.01$ & $0.71 \pm 0.02$ \\
\hline Pore size $(\mathrm{nm})$ & $1.23 \pm 0.02$ & $0.75 \pm 0.03$ \\
\hline Porosity (\%) & $56.28 \pm 1.98$ & $95.33 \pm 3.88$ \\
\hline Carbon (wt \%) & $35.72 \pm 1.12$ & $21.56 \pm 0.97$ \\
\hline Potassium (wt \%) & $14.35 \pm 0.09$ & $1.95 \pm 0.02$ \\
\hline Nitrogen (wt \%) & $2.16 \pm 0.06$ & $0.38 \pm 0.00$ \\
\hline Oxygen (wt \%) & $4.59 \pm 0.01$ & $0.41 \pm 0.01$ \\
\hline Sulphur (wt \%) & $3.05 \pm 0.02$ & $2.25 \pm 0.00$ \\
\hline Zinc (wt \%) & $3.25 \pm 0.56$ & $24.62 \pm 1.17$ \\
\hline Chlorine (wt \%) & $2.46 \pm 0.04$ & $7.64 \pm 0.07$ \\
\hline Calcium (wt \%) & $13.11 \pm 1.73$ & $4.34 \pm 0.05$ \\
\hline
\end{tabular}

reported for Borassus aethiopum shells AC (Jacob et al. 2017) but was less superior to $1.88 \%$ and $0.5 \%$, respectively, reported for coconut shell AC (Gawande and Kaware 2017).

The volatile matter of the HSC was lower than that of the HAC, while fixed carbon was greater. This is expected because carbonization temperature promoted the release of volatiles from breaking of bonds in organic matrices (Pechyen et al. 2007). HAC had high fixed carbon and low ash content which are the factors that substantiated its utilization in production of highperformance AC (Elelu et al. 2019).

The study showed that the HAC has larger surface area $\left(1029 \mathrm{~m}^{2} \mathrm{~g}^{-1}\right)$ which was significantly higher when compared to the surface area of the HSC $\left(440 \mathrm{~m}^{2} \mathrm{~g}^{-1}\right)$. Surface area is the summation of the external surface area and micropore area, and AC functions by the adhesion of substances to the walls of the pores. The greater the available surface area, the better the adsorption efficiency (Yusufu et al. 2012). The reported surface area of the HAC in this study fell within the range of $500-1500 \mathrm{~m}^{2} \mathrm{~g}^{-1}$ specification of ACs for water purification (Guillossou et al. 2019; Reza et al. 2020). The value reported for the HAC was in conformity with surface areas of $718-1018 \mathrm{~m}^{2} \mathrm{~g}^{-1}$ (Table 2) reported for water treatment ACs from some local raw materials (Yusufu et al. 2012) but was higher than $435.1 \mathrm{~m}^{2} \mathrm{~g}^{-1}$ reported for coconut shell AC (Gawande and Kaware 2017), 923 and $927 \mathrm{~m}^{2} \mathrm{~g}^{-1}$ reported for ACs produced from bagasse and rice husk, respectively (Boonpoke et al. 2011). The activating agent could have caused swelling of the molecular structure of the precursor's cellulose resulting in the breaking of bonds during carbonization (Saka 2102), which later led to the greater surface area in the HAC.

Furthermore, porous properties of the activated charcoal showed that the pore volume and pore size of the HAC exhibited type I adsorption isotherm according to IUPAC classification (Zdravkov et al. 2007; Hidayat and Sutrisno 2008; Reza et al. 2020), indicating the formation of microporous charcoal (higher porosity). The result of pore volume $\left(0.71 \mathrm{~cm}^{3} \mathrm{~g}^{-1}\right)$ for the HAC was higher compared to $0.53 \mathrm{~cm}^{3} \mathrm{~g}^{-1}$ and $0.56 \mathrm{~cm}^{3} \mathrm{~g}^{-1}$ (Table 2) determined in bagasse and rice husk ACs, respectively (Boonpoke et al. 2011). The pore size of the HAC $(0.75 \mathrm{~nm})$ was consistent with $0.80 \mathrm{~nm}$ found in both bagasse and rice husk ACs (Boonpoke et al. 2011). HAC with porosity of 95.33\%, agreed well with $96.22 \%$ reported for rice husk-activated carbon but lower than $99.19 \%$ reported for bagasse-activated carbon (Boonpoke et al. 2011).

The iodine number is an indication of the surface area of the pore in the adsorbent (Saka 2012). A higher iodine number signifies higher micro-porosity, hence better performance (Gawande and Kaware 2017). HAC with iodine number $1083 \mathrm{mg} \mathrm{g}^{-1}$ proved to be a better adsorbent than ACs (828 $-995 \mathrm{mg} \mathrm{g}^{-1}$ ) derived from local raw materials (Yusufu et al. 2012). The observed analytical differences could be ascribed to variation in porous properties such as porosity, surface area, pore size and pore volume of the adsorbents (Yusufu et al. 2012). In the same trend, the result obtained was higher than $942 \mathrm{mg} \mathrm{g}^{-1}$ reported for coconut shell AC (Gawande and Kaware2017). Iodine value of the HAC denotes that it has excellent adsorptive properties, which can be used for adsorption of organic and heavy metal pollutants (Elelu et al. 2019).

Elemental compositions of the HSC and HAC surfaces as revealed by ED-XRS found that the carbon contents were 35.72 and $21.56 \mathrm{wt} \%$, respectively. The decrease in the content is expected since decomposition of carbon took place in the presence of $\mathrm{ZnCl}_{2}$ (Mopoung et al. 2015). Other predominant elements present were calcium, potassium, nitrogen, oxygen and sulphur with atomic concentrations decreasing after activation (Table 1). Compositions of other elements are provided in the supplementary materials (Table S3). The implication of the presence of these elements in high proportion is that this adsorbent cannot be utilized to remove metal ions of those elements from aqueous media (Elelu et al. 2019). However, there was a progressive increase in the atomic concentrations of zinc and chlorine after the activation. This is expected since zinc chloride was used as activating agent and it was difficult to leach completely away after the activation (Saka 2012).

\section{Scanning electron microscopy studies}

The SEM images of the HSC and HAC are depicted in Fig. 3. A striking feature in these images is the appearance 


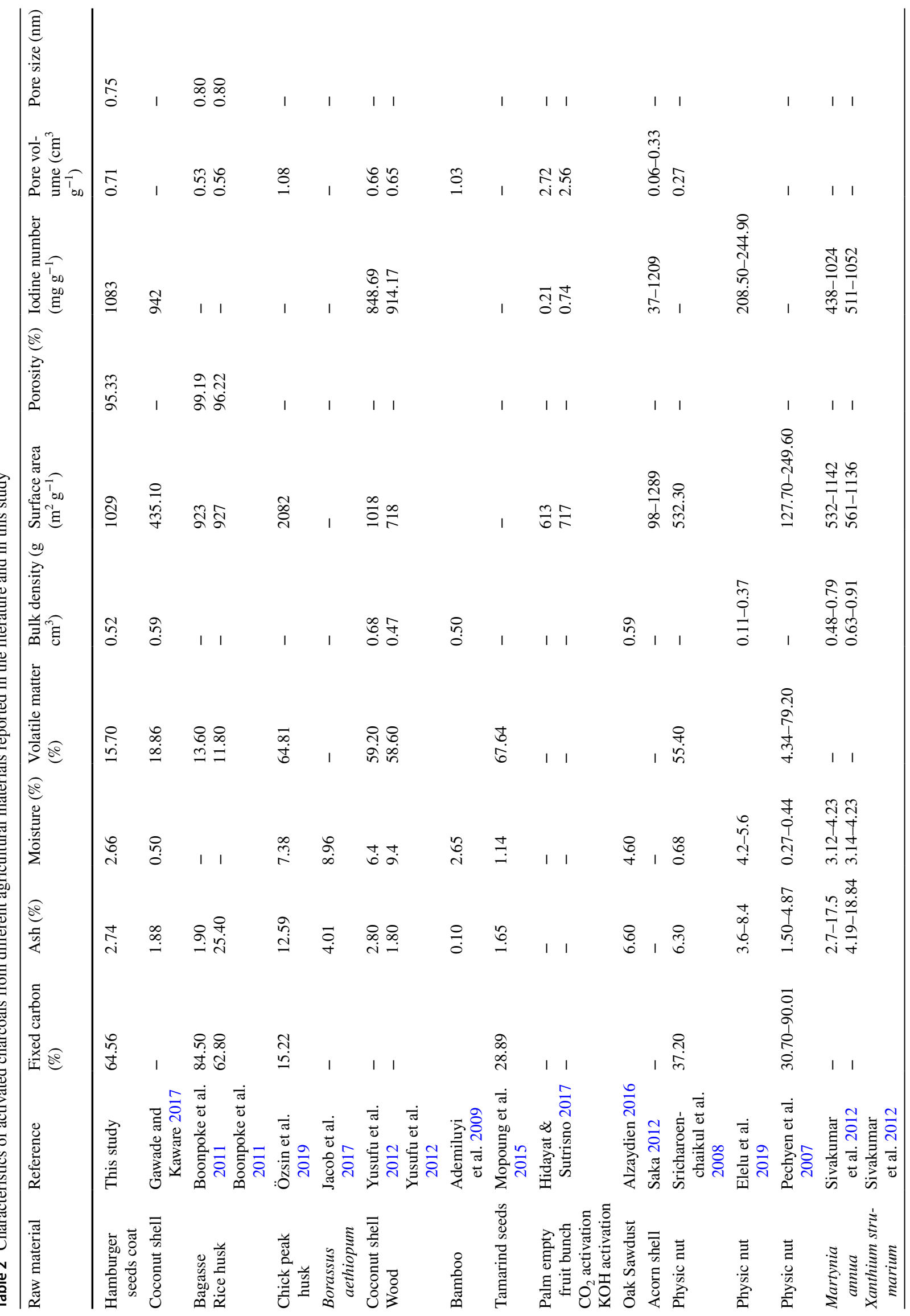


of porous internal structure in HAC. The HSC (Fig. 3a) displayed a smooth and non-porous surface, while the HAC (Fig. 3b) displayed a rough and microporous structure, which may offer more adsorption sites (Sricharoenchaikul et al. 2008), indicating that the HAC has been chemically modified. In the HSC (Fig. 3a), there existed regular size and shape of individual grains, whereas in the HAC (Fig. 3b), there existed irregular and heterogeneous surface morphology with variations of pores of different widths. This suggests that the activator has altered the surface structure of this biomass. It should be noted that development of pore structures on charcoal surface is influenced by factors such as initial structure of the precursor and inorganic impurities present (Elelu et al. 2019).

\section{Infrared studies}

The FTIR spectra of the HSC and HAC were recorded, and their respective IR absorption frequencies are shown in Fig. 4. The spectra showed notable differences in the absorption bands before and after the activation. The percentage transmittance of the entire peaks decreased, indicating an increase in absorbance which may be due to the formation of adsorption pores by the activating agent. The activation of carbonized HSC yielded a shift in the absorption band of O-H stretching vibration at $3261.4 \mathrm{~cm}^{-1}$ (Fig. $4 \mathrm{a}$ ) to $3257.7 \mathrm{~cm}^{-1}$ (Fig. 4b), indicating that a $\mathrm{C}-\mathrm{H}$ symmetric and asymmetric stretching vibrations of the aliphatic $-\mathrm{CH}_{2}$ had occurred during activation (Anderson et al. 2004). Bands at 1233.7 and $1159.2 \mathrm{~cm}^{-1}$ due to $\mathrm{C}-\mathrm{O}$ stretching of alcohols, phenols, ethers or esters (Anderson et al. 2004; Saka 2012) were not affected by the activation, but there was a significant decrease in their transmittances. Also unaffected were the peaks at 1051.1 and $823.7 \mathrm{~cm}^{-1}$ attributed to asymmetric and symmetric stretching, respectively, of the $\mathrm{Si}-\mathrm{O}$ bond (Pavia et al. 2015).

Further peaks in the finger print region revealed a clear differentiation with respect to the band at $637.4 \mathrm{~cm}^{-1}$ shifted to $603.8 \mathrm{~cm}^{-1}$. There was a significant decrease in the absorption frequency of the broad peak at $2926.0 \mathrm{~cm}^{-1}$ attributed to the symmetric stretching vibration of the aliphatic $-\mathrm{CH}_{2}$ (Pavia et al. 2015) in addition to the peak at $3261.4 \mathrm{~cm}^{-1}$ (Fig. 4a); there was a substantial shift in this band by almost 4 units. It was evident that the original strong absorption peak at $1561.8 \mathrm{~cm}^{-1}$ (Fig. 4a) assigned to ring vibration in a large aromatic skeleton generally found in carbonaceous materials (Palleros 2000; Saka 2012) shifted to $1543.1 \mathrm{~cm}^{-1}$ (Fig. 4b). During the chemical modification, peaks at $1364.2 \mathrm{~cm}^{-1}$ that shifted to $1304.6 \mathrm{~cm}^{-1}$ are an indication of the presence of aromatic groups (Pavia et al. 2015). Peak at $823.7 \mathrm{~cm}^{-1}$ as a result of $=\mathrm{C}-\mathrm{H}$ para di-substituted aromatic hydrocarbon confirmed the presence of aromatic ring (Pavia et al. 2015). Peak at $2374.3 \mathrm{~cm}^{-1}$ attributed to 
Fig. 3 Micrographs of a un-activated and $\mathbf{b}$ activated hamburger seed coat charcoal

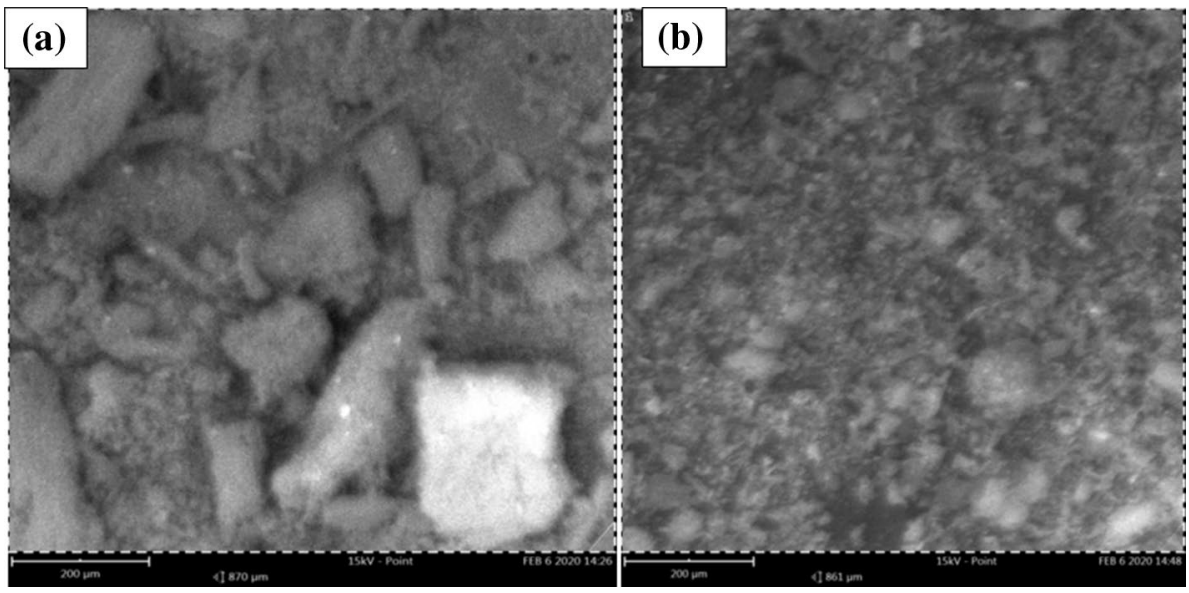

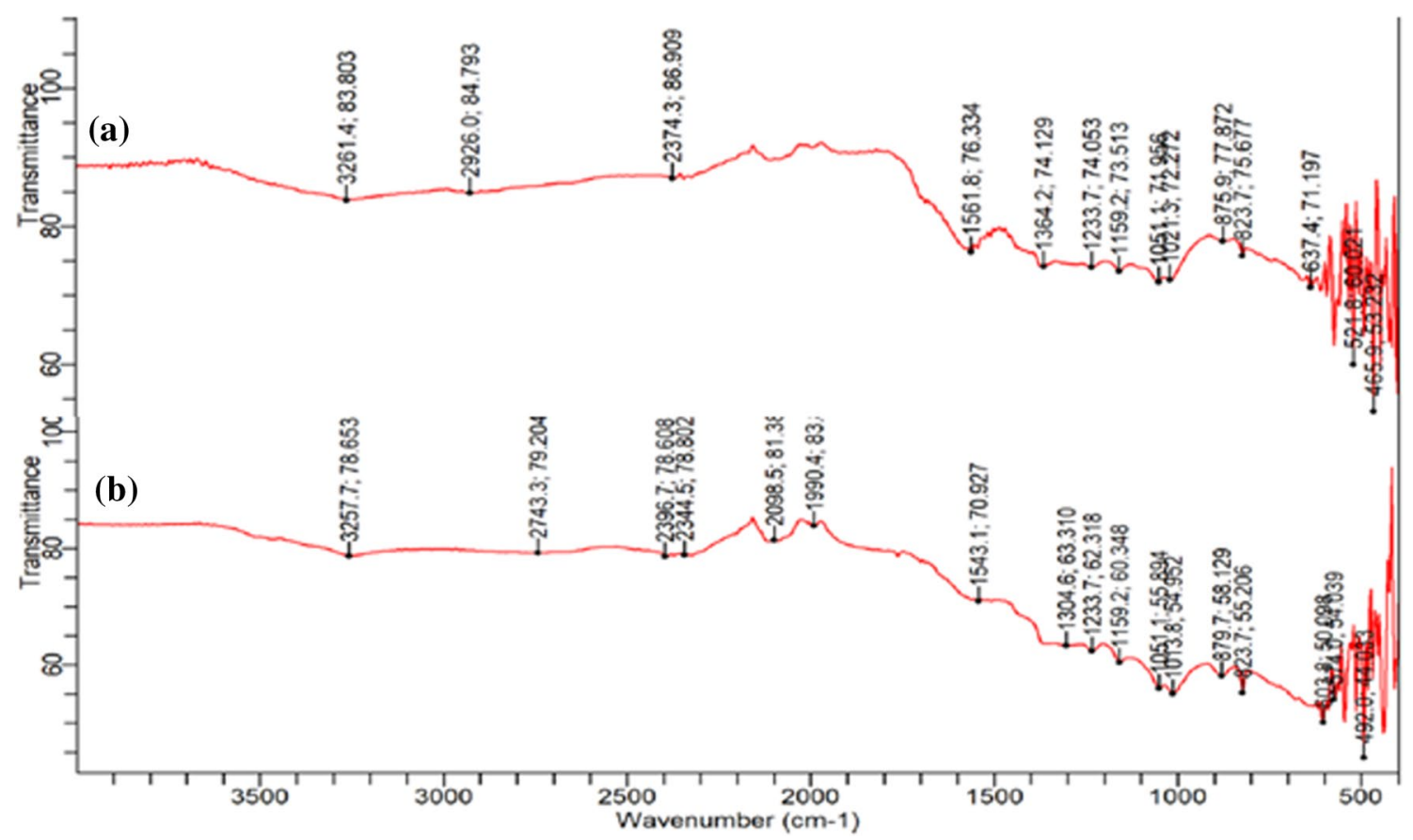

Fig. 4 IR spectra of $\mathbf{a}$ un-activated and $\mathbf{b}$ activated hamburger seed coat charcoal

$\mathrm{C} \equiv \mathrm{C}$ stretching vibration in alkynes (Saka 2012) shifted to $2344.5 \mathrm{~cm}^{-1}$ and generated another new absorption peak at $2396.7 \mathrm{~cm}^{-1}$. The shift in some absorption bands and the presence of new functional groups in the chemically modified sample proved that the chemical activation of the charcoal occurred.

\section{Physicochemical properties HAC- and CAC-treated and untreated water}

The results of the physicochemical properties of the contaminated surface water, the HAC-treated water and the CACtreated water are shown in Table 3 . The results indicated that the HAC had similar adsorption capacity with the CAC with respect to the parameters tested in the contaminated water. The original pale yellow and offensive odour of the water became clear and odourless when treated with the adsorbents. The removal of colour and odour in the contaminated water with the test adsorbent was similar to the report of Ademiluyi et al. (2009).

$\mathrm{pH}$ is an index of acidity or alkalinity of a substance and serves as an indicator that compares some of the most water-soluble ions. A water sample low in $\mathrm{pH}$ (acidic) may pose considerable health threats to humans (Okonkwo and Eboatu 2006). The adsorbent balanced the $\mathrm{pH}$ of the contaminated water to reasonable degree after the treatment, and the values were within the standard range of 6.5 to 9.5 specified by World Health Organization (WHO 2003), 
Standard Organization of Nigeria (SON 2007) and United States Environmental Protection Agency (USEPA 2012), thus indicating improvement in the water quality. The increment was higher than 0.53 achieved after wastewater was treated with waste bamboo AC (Ademiluyi et al. 2009).

TDS sums up the amount of non-filterable solids, and it is a measure of dissolved materials in a given sample of water. The test adsorbent reduced TDS of the contaminated water significantly, representing $67.6 \%$ reduction after treatment with HAC. The value obtained was far below the recommended limit $\left(500 \mathrm{mg} \mathrm{dm}^{-3}\right)$ of TDS in portable water (WHO 2003; SON 2007; USEPA 2012). The reduction was lower than $70.5 \%$ achieved with the CAC but more effective than $24.3 \%$ reduction achieved after contaminated water was treated with bamboo AC (Ademiluyi et al. 2009). It is a well-known fact that water sample with very high TDS is not useful for bathing, drinking and for industrial applications; such water is expected to have high osmotic potential, thereby making it to be a potential irritant of the skin (Okonkwo et al. 2007).

Further results in Table 3 showed that the adsorbent reduced TSS in the contaminated water to a lower value (from 120 to $42 \mathrm{mg} \mathrm{dm}^{-3}$ ) compared to the CAC (from 120 to $85 \mathrm{mg} \mathrm{dm}^{-3}$ ). TSS measures the residue remaining after the water evaporated and dried at a temperature between 103 and $105^{\circ} \mathrm{C}$ (Siong et al. 2013). Water sample with high TSS indicates low purity; such water usually possesses high BOD and $\mathrm{NO}_{3}^{-}$due to microbial oxidation of the suspended organics (Okonkwo et al. 2007).

Water medium with extreme alkalinity cannot support aquatic lives. In addition, the presence of alkalis in water influences the toxicity of inorganic pollutants (Okonkwo and Eboatu 2006). The values reported for alkalinity in this study for the untreated water, FCAC and FHAC were higher than the recommended value of $100 \mathrm{mg} \mathrm{dm}^{-3}$ (Table 3). However, alkalinity is not considered detrimental to humans but is generally associated with high $\mathrm{pH}$ values, hardness and excess dissolved solids (Okonkwo et al. 2007).

Table 3 Results of physicochemical properties of contaminated surface water treated with commercial activated charcoal (FCAC) and hamburger seed waste-activated charcoal (FHAC)

\begin{tabular}{|c|c|c|c|c|c|c|}
\hline Parameter & Untreated water & FCAC & FHAC & WHO limit (2003) & SON limit (2007) & USEPA limit (2012) \\
\hline $\mathrm{pH}$ & $5.52 \pm 0.10^{c}$ & $6.32 \pm 0.20^{\mathrm{b}}$ & $6.59 \pm 0.20^{\mathrm{a}}$ & $6.50-9.50$ & $6.50-8.50$ & $6.50-8.50$ \\
\hline Temperature $\left({ }^{\circ} \mathrm{C}\right)$ & $26.40 \pm 0.30^{\mathrm{b}}$ & $27.20 \pm 0.20^{\mathrm{a}}$ & $27.40 \pm 1.30^{\mathrm{a}}$ & $20-32$ & Ambient & NVA \\
\hline Odour & Offensive & Unobjectionable & Unobjectionable & Unobjectionable & Unobjectionable & $3 \mathrm{TON}$ \\
\hline Colour & 12.20 & 2.10 & 2.00 & 15 & 15 & 15 \\
\hline $\operatorname{TDS}\left(\mathrm{mg} \mathrm{dm}^{-3}\right)$ & $441 \pm 6.00^{\mathrm{a}}$ & $130 \pm 5.00^{c}$ & $143 \pm 2.80^{\mathrm{b}}$ & 500 & 500 & 500 \\
\hline $\operatorname{TSS}\left(\mathrm{mg} \mathrm{dm}^{-3}\right)$ & $120 \pm 2.00^{\mathrm{a}}$ & $85.00 \pm 4.00^{\mathrm{b}}$ & $42.00 \pm 2.21^{\mathrm{c}}$ & 500 & NVA & NVA \\
\hline Turbidity (NTU) & $0.87 \pm 0.05^{\mathrm{a}}$ & $0.21 \pm 0.10^{\mathrm{b}}$ & $0.16 \pm 0.01^{\mathrm{c}}$ & NVA & 5.00 & 0.50 \\
\hline Conductivity $\left(\mu \mathrm{cm}^{-1}\right)$ & $882 \pm 8.00^{\mathrm{a}}$ & $224 \pm 4.00^{\mathrm{b}}$ & $206 \pm 4.54^{c}$ & 1200 & 1000 & NVA \\
\hline Alkalinity $\left(\mathrm{mg} \mathrm{dm}^{-3}\right)$ & $154 \pm 1.01^{\mathrm{a}}$ & $132 \pm 2.30^{\mathrm{b}}$ & $107 \pm 3.41^{\mathrm{c}}$ & 100 & 100 & NVA \\
\hline Hardness $\left(\mathrm{mg} \mathrm{dm}^{-3}\right)$ & $36.00 \pm 2.70^{\mathrm{a}}$ & $19.00 \pm 2.00^{\mathrm{b}}$ & $16.00 \pm 1.06^{\mathrm{c}}$ & 100 & 150 & NVA \\
\hline $\mathrm{BOD}\left(\mathrm{mg} \mathrm{dm}^{-3}\right)$ & $56.80 \pm 3.08^{\mathrm{a}}$ & $19.80 \pm 1.40^{\mathrm{b}}$ & $10.20 \pm 0.34^{\mathrm{c}}$ & NVA & NVA & NVA \\
\hline $\operatorname{COD}\left(\mathrm{mg} \mathrm{dm}^{-3}\right)$ & $684 \pm 9.23^{\mathrm{a}}$ & $120 \pm 4.45^{\mathrm{b}}$ & $54.00 \pm 1.98^{c}$ & NVA & NVA & NVA \\
\hline $\mathrm{NO}_{3}^{-}\left(\mathrm{mg} \mathrm{dm}^{-3}\right)$ & $3.50 \pm 0.20^{\mathrm{a}}$ & $3.20 \pm 0.10^{\mathrm{b}}$ & $2.37 \pm 0.07^{\mathrm{c}}$ & 50 & 50 & 10 \\
\hline $\mathrm{SO}_{4}^{2-}\left(\mathrm{mg} \mathrm{dm}^{-3}\right)$ & $70.10 \pm 5.10^{\mathrm{a}}$ & $31.30 \pm 2.28^{\mathrm{b}}$ & $22.00 \pm 1.05^{\mathrm{c}}$ & 500 & 100 & 250 \\
\hline $\mathrm{PO}_{4}^{3-}\left(\mathrm{mg} \mathrm{dm}^{-3}\right)$ & $7.30 \pm 2.51^{\mathrm{a}}$ & $1.21 \pm 0.01^{\mathrm{b}}$ & $1.12 \pm 0.03^{\mathrm{c}}$ & NVA & NVA & NVA \\
\hline $\mathrm{Cl}^{-}\left(\mathrm{mg} \mathrm{dm}^{-3}\right)$ & $53.1 \pm 4.00^{\mathrm{a}}$ & $4.40 \pm 0.36^{\mathrm{b}}$ & $1.58 \pm 0.06^{\mathrm{c}}$ & 500 & 250 & 250 \\
\hline $\mathrm{Cd}^{2+}\left(\mathrm{mg} \mathrm{dm}^{-3}\right)$ & $<\mathrm{DL}$ & $<\mathrm{DL}$ & $<\mathrm{DL}$ & NVA & 0.003 & 0.005 \\
\hline $\mathrm{Ni}^{2+}\left(\mathrm{mg} \mathrm{dm}^{-3}\right)$ & $0.03 \pm 0.00^{\mathrm{a}}$ & $<\mathrm{DL}$ & $0.02 \pm 0.01^{\mathrm{a}}$ & NVA & 0.02 & 0.1 \\
\hline $\mathrm{Pb}^{2+}\left(\mathrm{mg} \mathrm{dm}^{-3}\right)$ & $0.01 \pm 0.00$ & $<\mathrm{DL}$ & $<\mathrm{DL}$ & 0.05 & 0.01 & 0.05 \\
\hline $\mathrm{Mn}^{2+}\left(\mathrm{mg} \mathrm{dm}^{-3}\right)$ & $0.40 \pm 0.01^{\mathrm{a}}$ & $<\mathrm{DL}$ & $0.20 \pm 0.01^{\mathrm{b}}$ & 0.4 & 0.2 & 0.05 \\
\hline $\mathrm{Fe}^{2+}\left(\mathrm{mg} \mathrm{dm}^{-3}\right)$ & $0.92 \pm 0.23^{\mathrm{a}}$ & $0.77 \pm 0.11^{\mathrm{b}}$ & $0.52 \pm 0.09$ & 3.0 & 0.3 & 0.3 \\
\hline $\mathrm{Zn}^{2+}\left(\mathrm{mg} \mathrm{dm}^{-3}\right)$ & $1.88 \pm 0.12^{\mathrm{b}}$ & $0.23 \pm 0.01^{\mathrm{c}}$ & $2.33 \pm 0.06^{\mathrm{b}}$ & NVA & 3 & 5 \\
\hline $\mathrm{Cu}^{2+}\left(\mathrm{mg} \mathrm{dm}^{-3}\right)$ & $0.30 \pm 0.00^{\mathrm{a}}$ & $0.19 \pm 0.00^{\mathrm{c}}$ & $0.21 \pm 0.01^{\mathrm{b}}$ & NVA & 1 & 1 \\
\hline $\mathrm{Cr}^{3+}\left(\mathrm{mg} \mathrm{dm}^{-3}\right)$ & $0.25 \pm 0.00^{\mathrm{a}}$ & $0.09 \pm 0.01^{\mathrm{c}}$ & $0.12 \pm 0.04^{\mathrm{b}}$ & 5.0 & 0.05 & 0.1 \\
\hline $\mathrm{AS}^{3+}\left(\mathrm{mg} \mathrm{dm}^{-3}\right)$ & $<\mathrm{DL}$ & $<\mathrm{DL}$ & $<\mathrm{DL}$ & NVA & 0.01 & 0.01 \\
\hline
\end{tabular}

${ }^{\mathrm{a}-\mathrm{c}}$ Means $\pm \mathrm{SD}$ with the same superscript letters within a row are not significantly different at $p=0.05 ;<\mathrm{DL}$ : less than detection limit; NVA: no value available 
The hardness of the untreated water sample was $36.0 \mathrm{mg} \mathrm{dm}^{-3}$, which revealed high concentration of dissolved salts of metals like calcium, magnesium and iron, which are important contributors of water hardness. There was significant difference $(p>0.05)$ in the hardness values recorded for the untreated water, FCAC and FHAC; however, there was appreciable reduction in hardness after the contaminated water passed through the HAC and CAC. Hard water may not have health effect but may form scale in boilers, water heaters, pipes, and cooking utensils (Okonkwo and Eboatu 2006).

Turbidity in water sample designates the quality of water with respect to colloidal and residual suspended matter (Sionget al. 2013). If turbidity is high, there is possibility of bacterial contamination, while low level of turbidity in water signifies appreciable purity (Okonkwo and Eboatu 2006). $\mathrm{HAC}$ was very effective in reducing the turbidity reading by $81.6 \%$ compared $64 \%$ achieved with the CAC. Yet, it was less effective compared to waste bamboo AC (Ademiluyiet al. 2009), in which $100 \%$ removal was recorded.

Conductivity is the property of a solution to conduct electricity as a result of high number of ionic constituents. It is directly related to mineral contents, which are TDS (Okonkwo et al. 2007). FHAC had a lower conductivity measurement compared to the FCAC and untreated water (Table 3), suggesting that the HAC had significant adsorption efficacies on the dissolved ions in the contaminated water. The low value measured in the HAC indicates that most of the dissolved ions had been removed by the adsorbent. Results obtained with contaminated water treated with the HAC and CAC were within the acceptable limits (WHO 2003; SON 2007; USEPA 2012). The observed reduction was also reflected in the lower values of metallic and nonmetallic ions determined in the FHAC and FCAC (Table 3).

BOD is a test used to measure the amount of oxygen consumed by the organisms during a specified period of time. It signifies organic pollution and measures the productivity of water. The higher the value, the more polluted the water sample (Okonkwo and Eboatu 2006). BOD in the untreated water was determined to be $56.80 \mathrm{mg} \mathrm{dm}^{-3}$, which confirms that the water was grossly polluted. After treatment with the $\mathrm{HAC}$, the value reduced to $10.20 \mathrm{mg} \mathrm{dm}^{-3}$. This confirms that the HAC removed $82 \%$ pollutants from the contaminated water compared to $65 \%$ achieved by the CAC. Similar degree of purification was observed in the results of Ademiluyi et al. (2009) with 74.8\% BOD reduction. However, the efficiency was lower compared to $96-99 \%$ achieved with Nigerian bamboo AC (Ijaola et al. 2013).

COD is a measure of the amount of a specified oxidant that reacts with the water sample under controlled condition (Siong et al. 2013). There were remarkable drops in the values of COD in FCAC and FHAC compared with untreated water (Table 3 ). Approximately $92 \%$ reduction was achieved with the HAC as an adsorbing agent. This result was better than $62.2 \%$ COD reduction in effluent treated with waste bamboo AC (Ademiluyi et al. 2009) but consistent with $90-97 \%$ COD reduction achieved with waste bamboo AC (Ijaola et al. 2013).

There were significant differences in the mean concentrations of $\mathrm{NO}_{3}^{-}, \mathrm{PO}_{4}^{3-}, \mathrm{SO}_{4}^{2-}$ and $\mathrm{Cl}^{-}$of the untreated water sample compared with test and control treated water samples. The results of these ions in the FHAC showed significant reduction in their concentrations. The low levels of these anions give credence to the prohibition of microbial growth (Okonkwo et al. 2007). Okonkwo and Eboatu (2006) opined that chloride concentrations above $250 \mathrm{mg} \mathrm{dm}^{-3}$ in drinking water may cause corrosion in the distribution system; produce an objectionable salty taste and a laxative effect. Such water may not be useful for bathing, drinking and for industrial applications; since it is expected to have high osmotic potential, thereby making the water to be a potential irritant of the skin (Okonkwo et al. 2007). The $\mathrm{HAC}$ reduced the concentration of chloride in the untreated water to $29.76 \%$.

Sulphate is a substance that is often found in drinking water. Health concerns of diarrhoea associated with drinking water containing high level of sulphate had been raised. Such water is not good for industrial applications because it may form a hard scale in boilers and heat exchangers (Okonkwo and Eboatu 2006). However, this may not be a cause for alarm since the HAC was able to reduce the sulphate content from $70.10 \mathrm{mg} \mathrm{dm}^{-3}$ (untreated water) to $22.0 \mathrm{mg} \mathrm{dm}^{-3}$. In another development, high concentrations of nitrate and phosphate in water result in eutrophication (excessive increase in population of microbiota). High levels of nitrate and phosphate in a water sample portend higher pollution (Okonkwo and Eboatu 2006). In this research, phosphate was found to be $1.12 \mathrm{mg} \mathrm{dm}^{-3}$ in the FHAC. This low value as compared to $7.30 \mathrm{mg} \mathrm{dm}^{-3}$ recorded in the untreated water may not pose any health hazard. The value of nitrate in the FHAC $\left(2.37 \mathrm{mg} \mathrm{dm}^{-3}\right)$ was lower compared to what was determined in the untreated water $\left(3.50 \mathrm{mg} \mathrm{dm}^{-3}\right)$ and in the FCAC $\left(3.20 \mathrm{mg} \mathrm{dm}^{-3}\right)$. The value was also found below maximum nitrate contaminant level (WHO 2003; SON 2007). If the nitrate is above the permissible recommended level, there is a great tendency for bacteriological pollution (Okonkwo and Eboatu 2006).

The metallic ions investigated in the contaminated water, some of which may be carcinogenic (As, $\mathrm{Pb}$ ), teratogenic $(\mathrm{Pb})$ and mutagenic $(\mathrm{Cd}, \mathrm{Ni}, \mathrm{Cu}, \mathrm{Pb})($ Okonkwo and Eboatu 2006), were completely removed, reduced below or within the limits of regulatory bodies' standards. The uptake of chromium by the HAC was excellent and was in agreement with the adsorption of some metals reported for chickpea AC (Özsin et al. 2019). When the concentrations of iron and manganese are above regulatory limits, they may cause browning and black stains on laundry, plumbing fixtures and 
sinks (Okonkwo and Eboatu 2006). The low values of iron and manganese observed in the FHAC were within tolerable limits and may not cause health challenge. The total uptake of lead with the adsorbent was remarkable; this result compared favourably with $99.67 \%$ lead adsorbed with Borassus aethiopum shell AC (Jacob et al. 2017). Concentration of zinc in the FHAC was higher than in both the untreated water and FCAC. This is expected since $\mathrm{ZnCl}_{2}$ was used as activating agent which might have added up to the $\mathrm{Zn}^{2+}$ concentration in the HAC treatment. However, the level of $\mathrm{Zn}^{2+}$ was still below the recommended limits (WHO 2003; USEPA 2012). Inability to extract zinc completely from ACs has been reported as a drawback of using $\mathrm{ZnCl}_{2}$ as an activating agent (Ijaola et al. 2013; Ajala et al. 2020).

\section{Conclusion}

This study assessed the feasibility of converting hamburger seed coat (an agricultural waste) into an AC. The AC produced had adsorption capacity comparable to those of high-performance adsorbents. The significant reduction of contaminants in contaminated water by the HAC below the regulatory limits bares credence to its adsorption efficacy in the treatment of contaminated water. The study had therefore revealed that hamburger seed coat, hitherto considered as waste, could be converted into an $\mathrm{AC}$ for water treatment. This alternative beneficial use of hamburger seed coat could serve as a better solid waste management option that will greatly enhance the aesthetic values of our environment. Further similar research on other agricultural solid wastes is encouraged to completely transform solid wastes constituting environmental nuisance into value added products.

Supplementary Information The online version contains supplementary material available at https://doi.org/10.1007/s13762-021-03577-8.

Acknowledgements The authors express their profound gratitude to the Department of Science Laboratory Technology of Akanu Ibiam Federal Polytechnic, Unwana, Nigeria, for providing the facilities for this study. Also, the technical assistance of Gabriel Ocheja and Olusola Akinola of National Steel Raw Materials Exploration Agency, Kaduna, Nigeria and Central Laboratory of Obafemi Awolowo University, IleIfe, Nigeria, respectively, is appreciated.

Funding This research was proudly supported and sponsored by Tertiary Education Trust Fund (TETFund) of the Federal Republic of Nigeria.

\section{Declarations}

Conflict of interest The authors declare that they have no known competing financial interests or personal relationships that could have appeared to influence the work reported in this paper.

\section{References}

Abdul-Khalil HPS, Jawaid M, Firoozian P, Rashid U, Islam A, Akil AM (2013) Activated carbon from various agricultural wastes by chemical activation with $\mathrm{KOH}$ : Preparation and characterization. J Biobased Mat Bioenergy 7(6):708-714. https://doi.org/10.1166/ jbmb.2013.1379

Abraham FA, Thenmozhi R, Sivakumar M, Sivakumar K, Sasikumar G, Thamaraimuthuayyanraj S (2018) Waste water treatment unit using activated charcoal. Intl Res J Eng Tech 5(3):312-315

Ademiluyi FT, Amadi SA, Amakama NJ (2009) Adsorption and treatment of organic contaminants using activated carbon from waste Nigerian bamboo. J Appl Sci Environ Manage 13(3):39-47. https://doi.org/10.4314/jasem.v13i3.55351

Ajala LO, Onwukeme VI, Oji CO, Ejiagha MC (2020) Sustainable utilization of rice husk activated charcoal as wastewater decontaminant. In: Tüzemen S (ed) New insights into physical science (vol 2).Book Publisher International, India, pp 111-125. Doi: https:// doi.org/10.9734/bpi/nips/v2

Al-Qodah Z, Shawabkah R (2009) Production and characterization of granular activated carbon from activated sludge. Braz J Chem Eng 26(1):127-136. https://doi.org/10.1590/S0104-6632200900 0100012

Alzaydien AS (2016) Physical chemical and adsorptive characteristics of local oak sawdust based activated carbons. Asian J Sci Res 9:45-56. https://doi.org/10.3923/ajsr.2016.45.56

Anderson RA, Bendell DJ, Groundwater PW (2004) Organic spectroscopic analysis. The Royal Society of Chemistry, Cambridge

AOAC (2000). Method of analysis, (17th edn). Association of Official Analytical Chemists, Washington

APHA (2005) Standard methods for the examination of water and waste water (21th edn). American Public Health Association, Washington

ASTM (2006) Standard test method for determination of iodine number of activated carbon. ASTM committee on standards, Philadelphia

Boonpoke A, Chiarakorn S, Laosiripojana N, Towprayoon S, Chidthaisong A (2011) Synthesis of activated carbon and MCM-41 from bagasse and rice husk and their carbon dioxide adsorption capacity. J Sust Energy Environ 2:77-81. https:// www.researchgate.net/publication/266895645

Chakraborty S, De S, DasGupta S, Basu JK (2005) Adsorption study for the removal of basic dye: Experimental and modeling. Chemos 58(8):1079-1086. https://doi.org/10.1016/j.chemosphere. 2004.09.066

Elelu S, Adebayo GB, Abduls-Salam N, Iriowen EM (2019) Preparation and characterization of adsorbents from physic nut plant (Jatropha curcas L.). The Chemist 91(2):42-49

Gawande PR, Kaware JP (2017) Characterization and activation of coconut shell activated carbon. Intl J Eng Sci Inv 6(11):43-49

Gokhale NA, Trivedi NS, Mandavgane SA, Kulkarni BD (2020) Biomass ashes as potent adsorbent for pesticide: Prediction of adsorption capacity by artificial neural network. Intl J Environ Sci Tech 17:3209-3216. https://doi.org/10.1007/ s13762-020-02645-9

Guillossou R, Le Roux J, Mailler R, Vulliet E, Morlay C, Nauleau F, Gasperi J, Rocher V (2019) Organic micropollutants in a large wastewater treatment plant: What are the benefits of an advanced treatment by activated carbon adsorption in comparison to conventional treatment? Chemos 218:1050-1060. https:// doi.org/10.1016/j.chemosphere.2018.11.182

Hegazi HA (2013) Removal of heavy metals from wastewater using agricultural and industrial wastes as adsorbents. HBRC Journal 9(3):276-282. https://doi.org/10.1016/j.hbrcj.2013.08.004

Hidayat A, Sutrisno B (2017) Comparison on pore development of activated carbon produced by chemical and physical activation 
from palm empty fruit bunch. In: IOP conference series: materials science and engineering. Second international conference on chemical engineering (ICCE) UNPAR 26-27 October 2016, Bandung, Indonesia. http://dx.doi.org/https://doi.org/10.1088/ 1757-899X/162/1/012008

Ijaola OO, Ogedengbe K, Sangodoyin AY (2013) On the efficacy of activated carbon derived from bamboo in the adsorption of water contaminants. Int J Eng Inv 2(4):29-34. https://www.resea rchgate.net/publication/344814972

Jacob AG, Okunola OJ, Uduma AU, Tijjani A, Hamisu S (2017) Treatment of waste water by activated carbon developed from Borassus aethiopum. Nig J Mat Sci Eng 6(1):103-107. https:// www.researchgate.net/publication/319044454

Kurniawan TA, Chan GYS, Lo W, Babel S (2006) Physico-chemical treatment techniques for wastewater laden with heavy metals. Chem Eng J 118(1-2):83-98. https://doi.org/10.1016/j.cej.2006. 01.015

Marichelvan MK, Azhagurajan A (2018) Removal of mercury from effluent solution by using banana corm and neem leaves activated charcoal. Environ Nanotech Monit Manage 10:360-365

Martin MJ, Artola A, Balaguer MD, Rigola M (2003) Activated carbons developed from surplus sewage sludge for the removal of dyes from dilute aqueous solutions. J Chem Eng 94:231-239. https://doi.org/10.1016/S1385-8947(03)00054-8

Mopoung S, Moonsri P, Palas W, Khumpai S (2015) Characterization and properties of activated carbon prepared from tamarind seeds by $\mathrm{KOH}$ activation for Fe (III) adsorption from aqueous solution. The Sci World J. https://doi.org/10.1155/2015/415961

Okonkwo EM, Eboatu AN (2006) Environmental pollution and degradation, 2nd edn. Abimac Publishers, Awka, Nigeria

Okonkwo TJ, Ezeani-Obi MC, Chinwuba AJ, Okonkwo CJ (2007) Portability and biosafety of the water supply network at Nnamdi Azikiwe University temporary site, Awka. Nigeria Anachem J 1(1 \& 2):90-97

Olagunju EO, Ajala LO, Farombi AG (2105) Sustainable utilization of rice husk activated charcoal through phytoremediation. Phy Sci Intl J 5(2):81-87. Doi: https://doi.org/10.9734/PSIJ/2015/ 12318

Özsin G, Kılıç M, Apaydın-Varol E, Pütün AE (2019) Chemically activated carbon production from agricultural waste of chickpea and its application for heavy metal adsorption: equilibrium, kinetic, and thermodynamic studies. Appl Water Sci 9:56. https://doi.org/10.1007/s13201-019-0942-8

Palleros DL (2000) Experimental organic chemistry. John Wiley and Sons Inc., New York

Pavia DL, Lampman GM, Kriz GS, Vyvyan JR (2015) Introduction to spectroscopy, 5th edn. Cengage Learning, USA

Pechyen C, Atong D, Aht-ong D, Sricharoenchaikul V (2007) Investigation of pyrolyzed chars from physic nut waste for the preparation of activated carbon. J Solid Mech Mat Eng 1(4):498-507. https://doi.org/10.1299/jmmp.1.498

Rahman MA, Asadullah M, Haque MM, Motin MA, Sultan MB, Azad MAK (2006) Preparation and characterization of activated charcoal as an adsorbent. J Surf Sci Technol 22(3 \& 4):133-140

Rangaraj S, Moon SH, Sivabalan R, Arabidoo B, Murugesan V (2002) Agricultural waste for the removal of organics: adsorption of phenol from water and wastewater by palm seed coat activated carbon. Waste Manage 22(5):543-548. Doi: https:// doi.org/10.1016/s0956-053x(01)00016-2
Reza MS, Hasan ABM, Afroze K, Abu-Bakar MS, Taweekun J, Azad AK (2020) Analysis on preparation, application, and recycling of activated carbon to aid in Covid-19 protection. Intl J Integ Eng 12(5):233-244. Doi: https://doi.org/10.30880/ijie.2020.12. 05.029

Saka C (2012) BET, TG-DTG, FT-IR, SEM, iodine number analysis and preparation of activated carbon from acorn shell by chemical activation with $\mathrm{ZnCl}_{2}$. J Anal Appl Pyro 95:21-24. https:// doi.org/10.1016/j.jaap.2011.12.020

Singh J, Mishra V (2021) Synthesis and characterization of activated carbon derived from Tectona grandis sawdust via green route. Environ Prog Sust Energy. https://doi.org/10.1002/ep.13525

Singh J, Yada P, Pal AK, Mishra V (2020) Water pollutants: Origin and status. In: Pooja D, Kumar P, Singh P, Patil S (eds) Sensors in water pollutants monitoring: role of material. Springer, Singapore. pp 5-20. Doi: https://doi.org/10.1007/ 978-981-15-061-0_2

Siong YK, Idris AJ, Atabaki MM (2013) Performance of activated carbon in water filters. Water Res. https://www.researchgate. net/publication/234060484

Sivakumar V, Asaithambi M, Sivakumar P (2012) Physic-chemical and adsorption studies of activated carbon from agricultural wastes. Adv Appl Sci Res 3(1):219-226

SON (2007) Nigerian standard for drinking water quality. Standard Organization of Nigeria. Nigerian Industrial Standard (NIS) Governing Council, Lagos

Sricharoenchaikul V, Pechyen C, Aht-ong D, Atong D (2008) Preparation and Characterization of activated carbon from the pyrolysis of physic nut (Jatropha curcas L.) waste. Energy Fuels 22(1):31-37. Doi: https://doi.org/10.1021/ef700285u

Subramani T, Revathi PK (2015) Production of activated carbon from agricultural raw waste. J Eng 5(5):54-63

Ukpaka CP, Edwin I (2013) Adsorbent in bioremediation of crude oil polluted environment: Influence of physicochemical characteristics of various saw dusts. Intl Res J Biotechnol 4(7):124-141. Doi: https://doi.org/10.14303/irjob.2013.026

USEPA (2012) Drinking water standards and health advisories. United State Environmental Protection Agency, Washington

Wang J, Wu F, Wang M, Qui N, Liang Y, Fang S, Jiang S (2010) Preparation of activated carbon from a renewable agricultural residue of pruning mulberry shoot. Afr J Biotechnol 9(19):2762-2767. https://www.researchgate.net/publication/ 268366400

WHO (2003) Guidelines for drinking water quality. World Health Organization, Geneva, pp 112-113

Yusufu MI, Ariahu CC, Igbabul BD (2012) Production and characterization of activated carbon from selected local raw materials. Afr J Pure Appl Chem 6(9):123-131. https://doi.org/10.5897/ AJPAC12.022

Zdravkov BD, Čermák JJ, Šefara M, Janků J (2007) Pore classification in the characterization of porous materials: a perspective. Cent Euro J Chem 5(2):385-395. https://doi.org/10.2478/ s11532-007-0017-9

Zhou G, Ying G, Liu S, Zhou L, Chenand Z, Peng F (2014) Environmental science: processes and impacts 16(8). Doi: https://doi.org/ $10.1039 / \mathrm{c} 4 \mathrm{em} 00094 \mathrm{c}$ 